\title{
The Impact of Psychological Influences on Consumer Buying Behavior of SMEs' Products: A Case Study of the Manufacturing Sector in Zimbabwe
}

\author{
Godwell Karedza ${ }^{1 \bowtie}$ \\ Mike Sikwila ${ }^{2}$ \\ T.B. Bhebhe ${ }^{3}$
}

'Department of International Marketing Chinhoyi University of Technology, Chinhoyi, Zimbabwe 'Department of Consumer Science Chinhoyi University of Technology, Chinhoyi, Zimbabwe ${ }^{s}$ Graduate Business School Chinhoyi University of Technology, Chinhoyi, Zimbabwe

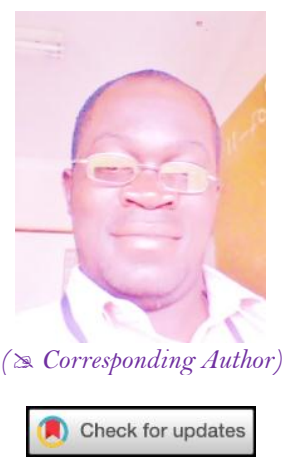

\begin{abstract}
The aim of this study was to determine the impact of psychological influences on the buying pattern of SMEs products in Zimbabwe. This study was motivated by the desire to establish the reason why SMEs products were failing to gain customers acceptance. Furthermore SMEs products have been observed to be occupying minimum shelf space in most of the supermarket in Zimbabwe as compared to foreign manufactured products. Zimbabwe has become an import destination, where almost every country is targeting to supply their products to the Zimbabwean supermarkets. The objectives of this study was to determine the effect of personality on the buying pattern of SMEs products in Zimbabwe, to determine the effect of customer perception on SMEs products and to determine the impact of attitudes on consumer purchasing behaviour of SMEs products. A sample of 100 respondents from customers and policy advocates were considered for this study. Stratified random sampling technique was used to select customers who buy SMEs products while policy makers were purposively sampled. The results revealed that personality greatly affects the purchasing behaviour of SMEs products in Zimbabwe, most of the respondents also revealed their negative perception towards any product from SMEs, while some revealed a negative attitude towards SMEs products as they articulated that they have a strong belief that SMEs are generally custodians of manufacturing poor quality products and due to this reason they choose to do business with big firms. The study concluded that psychological influences have an impact on consumer purchasing behaviour of SMEs products in Zimbabwe.
\end{abstract}

Keywords: SMEs, Personality, Buying, behaviours, Perception.

\section{Introduction}

SMEs are considered as the main economic engine for the prosperity of the country since they provide employment to a number of people in a country, they provide basic components which are an ingredient to the functionality of many industries in an economy, thus more emphasis must be put on developing appropriate methodologies that ensure their sustainability and their continued existence.

\subsection{Background to the Study}

Zimbabwean economy has become more of an import destination especially goods from our neighbouring countries are dominating the markets. Since 2009 when Zimbabwe started recovering from hyperinflation, there was a situation where all products were coming from South Africa, including fruits, cooking oil, drinks (Sibanda, 2015). The economy seems to be recovering from hyperinflation and the SME manufacturing sector is also rejuvenation from terrible economic hardships that rocketed Zimbabwe. The economy has also experienced the birth of SMEs who are effectively manufacturing quality products (Muleya, 2015). Despite these remarkable developments, the Zimbabwe markets have been flooded by foreign products and this has become a major barrier for the operations of local SME manufacturing firms. During a buy Zimbabwe initiative tour held in Bulawayo Zimbabwe, the PPC managing director stated that South Africa has brought 1.3 million tonnes of cement in the country and is expected to bring another 1.5 million tonnes (Majaka, 2015), a condition which seems to suggest that the import habit is still continuing. Although, the Zimbabweans in general own manufacturing factories of cement that can adequately satisfy the local market. Again horticultural products are also among the foreign products that are currently flooding the local supermarkets (Muleya, 2016). The concern is that the same products are also produced in Zimbabwe; therefore these situations are trade barriers to local producers who are in various manufacturing sectors. Besides the fact that the Zimbabwean market has been flooded by foreign products, some Zimbabweans decide to travel abroad to buy some products that are also manufactured in Zimbabwe (Muleya, 
2015). Products like furniture, cooking oil, blankets, and soap are produced in Zimbabwe, but it is quite amazing that some Zimbabweans actually travel to Botswana, South Africa and other countries to buy such products. This scenario has forced the Zimbabwean Revenue Authority (ZIMRA) to exclude most of these products on the travellers rebate. Goods that are no longer included on the travellers rebate include; products imported for commercial purposes; excess alcoholic beverages, stoves, refrigerators, blankets, cooking oil; and laundry bar soap (Majaka, 2015). This action by ZIMRA has been done to protect local firms and to stimulate Foreign Direct Investment (FDI). Zimbabwean consumers are shunning local produce and prefer foreign products, a condition which is quite shocking. Similarly, the SMEs in the manufacturing sector have not been spared. It is envisaged that psychological factors are among the potential factors fuelling the rejection of certain product by consumer and these factors include; perceptions, attitudes, personalities and beliefs. Some people can be described as 'high' in consumer ethnocentrism, for example the willingness to accept a foreign product (Schiffman, 2010). Kim and Chung (2011) argue that attitudes are among the salient factors that influence consumer behaviour. It is believed that individuals will be more interested to do a certain activity especially if they are inclined favourably towards it.

There is a clear cut between psychological influence and consumer purchasing behaviour and the researchers envisaged that this might have contributed to the shunning of SME locally manufactured products. This study focused on perceptions, attitudes, personality and beliefs as psychological influences associated with rejection of SME local produced products. Blythe (2011) assets that personality is a combination of various factors that determine who we are. Schiffman (2010) also highlighted that personalities are inner psychological factors that inclusively determine and reflect how an individual responds to the environment. Individual's personality cannot be easily changed as compared to an attitude. Perception on the other hand is all about how we make sense of the world and beliefs are generally mapped by the culture of an individual. Relating these factors to the scenario describe above, it seems to suggest that there is a link between psychological factors and consumer buying pattern of SMEs locally manufactured products.

\subsection{The Research Problem}

Local manufactures especially SMEs are facing a threat of foreign manufactured products and as such, most customers preferred to buy foreign products as compared to local products. This has impacted negatively both on the SMEs manufacturing industry and the economy in general. Productivity from locally manufactured products by the SMEs has been drastically going down and demand of these products by local consumers was becoming so unfavourable, thus negatively affecting Gross Domestic Product (GDP) of the country as more customers channelled their foreign currency towards the importation of foreign products thereby making the local SMEs products uncompetitive in the local market, hence affecting the nation at large. In this sense, the researchers were keen to establish whether the purchasing habits of consumers were associated with the psychological influences or not?

\subsection{Research Questions}

1. What is the impact of personality on consumer purchasing behaviour of SMEs locally manufactured goods in Zimbabwe?

2. What is the impact of customer perception on consumer buying pattern of SMEs manufactured products in Zimbabwe?

3. What is the effect of attitudes on consumer purchasing intentions of SMEs manufactured goods in Zimbabwe?

\section{Literature Review}

\subsection{The Impact of Personality on Consumer Purchasing Behaviour}

Personality can be referred to as the dynamic organization of psycho physiological systems that shapes an individual's characteristic pattern of behaviour, feeling, and thoughts (Lin, 2010). The paradox of personality in marketing assets that 'we all have a personality, but we do not know how it is systematically related to our behaviour as consumers' (Boddy and Croft, 2016). Consumers are therefore likely to use a brand in line with their personality traits (Lin, 2010). In this instance, marketers effort should focus on creating programmes and activities that encourages consumers to believe and recognise a brand personality and ensuring effective communication between the brand and the consumer (Govers and Schoormans, 2012). Consumers buy brands not for their functionality purposes only, rather they purchase these brands especially if they reflect their personalities. Thus, they tend to prefer brands consistent with their personalities (Banerjee, 2016). Most researchers who normally study 'personality' in marketing usually focus much on individual personality on product usage, preference, and the decision process. Marketers impose human personality traits on their brands, and believe that consumers relate to those brands as they would do to partners or friends. However, it should be noted that human personality characteristics may not translate directly into brand personality traits. Therefore, marketers should ensure an accurate alignment between the personality of the consumer and brand personality if they want to be successful in marketing, as most of the consumer's personality traits are associated with the brand. Consumers have senses that decode the signals of a brand sends out to them and develop individual and subjective perceptions of the brand's personality especially if the brand is poor (Ivens and Valta, 2012). Consumers normally prefer brands with personalities similar to their own and often choose brands because they view themselves as the type of person who would use the brand (Huang et al., 2012). The higher the fit between human personality and brand personality, the higher is the consumer's tendency to choose that brand (Lin, 2010).

\subsection{The Trait Theory}

The Trait Theory is a well known school of thought in personality psychology; many researchers' who studied human personality derived similar conclusions in their studies. Personality is the dynamic organization of psycho physiological systems that shapes a person's characteristic pattern of behaviour, thoughts, and feeling (Das, 2014). 
Other personality trait researchers concluded that for the most part, personality traits are generated by nature and are stable, but some others indicated that personality traits will continue to evolve and may even change, although the natural-born temperament may never change (Mohammad, 2015). The Trait Theory may be categorised into two schools. The first school is of the opinion that people are believed to have the same set of traits, and the reason for the difference is due to the fact that the level of each trait is shown differently. Therefore, it is a fact that traits are there in every individual. The second thought is that, individual variance is as a result of the trait combination, which varies from one person to another, and as such everyone has his/her own set of traits (Anant and Verma, 2014). Mohammad (2015) categorized traits into three types: cardinal traits, central traits and secondary traits. The traits are relatively long lasting styles of thinking, feeling, and acting, which makes individuals to be different from one another (Das, 2014). A lot of theories have been advanced to explain the personality principle, however evidence from literature suggest that there seems to be no single commonly accepted definition that exists. Das (2014) defines personality as the distinctive patterns of behaviour, including thoughts and emotions that characterize each individual's adaption to his or her life situation. This definition has been widely accepted among marketing researchers. Other researchers have categorised personality into two groups; the first group classifies personality as a set of internal traits that dictate a person's consistent and characteristic response to stimuli which explain a person's behavioural tendencies (Kotler, 2011). The second group relates personality as an interaction of the individual and the external situation he/she is in (Jani and Han, 2014). Both of these focuses mainly on examining issues that will enable researchers to predict, modify and control human behaviour, relying greatly on knowledge from psychology, sociology and psychiatry (Lin, 2010). The personality theories have received wide acceptance in explaining consumer behaviour and have been termed trait-based theories (Hawkins et al., 2010). The trait-based theories of personality try to describe human being in one or more series of traits (Das, 2014).

\subsection{The Big Five Model}

Ekhlassi et al. (2012) classify personality traits into five factors which are extroversion, agreeableness, conscientiousness, neuroticism, and openness. These factors above are normally referred to as the Big Five Model, which is commonly used to explain human behaviour. Jani and Han (2014) highlight that the five broad-level personality traits vary in degree, from low to high, among different individuals. Firstly, 'agreeableness' is described as an individual's concern for working together in social harmony, and the behavioural characteristics include being considerate, friendly, helpful, generous, and willing to forgo other things for others. In this instance, a score which is high shows adaptability and value getting along with others, while a low score indicates scepticism, challenging others' ideas, and reluctant to get involved (Mulyanegara, 2010). Secondly, 'conscientiousness' is described as the way individuals' regulate, control, and direct their impulses in decision-making behaviours. High scores indicate focus, being careful, reliable, and well organized, whereas low scores indicate distraction, disorganization, having flexibility, and being causal (Jani and Han, 2014). Thirdly, 'extraversion' is described as being assertive, action oriented, and typifies individuals who enjoy opportunities for excitement, attention drawing, and talking. Low scores indicate introversion, a person who likes to stay in the background, is less talkative, reserved in speech and less action oriented (Mohammad, 2015). Fourthly, 'neuroticism' is described as excessive worry that causes mental distress, emotional suffering, and an inability to cope with day-to-day life activities. High scores indicate emotional-reactive behavioural related to negative feelings such as anxiety, anger, or depression, whereas low scores indicate resilience, calmness and ability to control urges and stress (Mulyanegara, 2010). Fifthly, 'openness to experience' is described as being intellectually curious, open to new ideas, involves imaginative and creative cognition styles. A score which is high signifies an intellectual curiosity which is broad, whereas low scores show a preference for familiarity, narrow, and conservative intellectual focus. Mulyanegara (2010) observes significant relationships between some of the Big Five dimensions (e.g., extroverts prefer sociable brands) and brand preference type. Therefore, one can conclude that consumers prefer a specific brand when the brand resonates with their behaviours.

\subsection{Empirical Evidences on Personality and Consumer Buying Behaviour}

Migliore (2011) conducted a research on the buying intentions of sports shoes by the college students'. The idea was to find if there was a relationship between personality trait and brand personality. The researcher classified the brands into two categories namely; the ones preferred by college students and the ones actually being purchased, the study revealed that the students from the college have significant differences in their brand preferences. Govers and Schoormans (2012) further probed whether consumers' preference would be influenced when their self-concept is in conformity with product personality. Anant and Verma (2014) investigated the influence of brand personality on consumers' brand preference, loyalty, affection and purchasing intention. The results showed that brand personality has a positive influence on brand preference, loyalty, affection, and purchase intention. It might be that consumers like the brands having more distinct brand personality or consumers choose brands they are more familiar with. Xiaoling et al. (2011) investigated the relationships among the personality traits of openness and extroversion, hedonic value, brand affection and brand loyalty. The results revealed that openness and extroversion have a positive correlation on the loyalty of the brands or products with hedonic value.

\subsection{The Impact of Attitudes on the Buying Behaviour of Consumers}

Consumer attitudes usually include beliefs about, feelings about, and behavioural intents concerning something (Tanner and Kast, 2010). These components are grouped together as they relate and influence how individuals react to the objects. Nepomuceno and Porto (2010) assert that personal values influence most of the individual behaviours. Values are goals that guide our lives and influence our behaviour. The following forms component parts of attitudes namely; beliefs and affects. Firstly, beliefs are components of attitudes. Consumers may have both positive beliefs toward an item as well as negative beliefs (Mulyanegara, 2010). Furthermore, some beliefs might be neutral, and others may differ depending with the person. The beliefs that consumers have a need may not be accurate (e.g. that pork contains little fat), and other beliefs might upon close examination be contradictory (e.g. 
that a historical figure was a good person but also owned slaves). It might often be tough to get down to a "bottom line" concerning whether an item is good or bad since a consumer holds many beliefs about a particular product (Cohen and Reed, 2011). Secondly affect is also a component of attitudes for example; sometimes consumers may also hold some feelings to a product. These feelings may be based on the beliefs (e.g. a person feels nauseous when thinking about a hamburger because of the tremendous amount of fat it contains), but there may also be feelings which are relatively free of beliefs.

\subsubsection{Behavioral Intention}

The behavioural intention is usually what a consumer planned to do. As with affect, this is sometimes a logical consequence of beliefs, but may sometimes reflect other circumstances (Mulyanegara, 2010). The image depicted by a company and its products is of supreme importance, because this image is congruent with human values. Therefore, a customer may select a product simply because it portrays values that may be negatively or positively related to his/her personal values. One's attitude is an important mediator on the relationship between personal values and behaviour. Attitudes are defined as an enduring set of beliefs about an object that predisposes people to behave in particular way toward the object (Gupta and Ogden, 2009). Evidence has shown that personal values can influence attitudes, which in turn influence behaviour (Nepomuceno and Porto, 2010). Attitudes are quite malleable (Cohen and Reed, 2011) and may be influenced by the experience with a product. This poses some questions as to, what would be the relationship between values and attitudes after an individual had experienced a negative incident with a service? Will this incident decrease their relationship, indicating that the attitude is no longer expressing one's values? More importantly, the service recovery efficiency may increase if one aligns the response to the customer's value system. The relationships that exist between attitudes values and behaviour would be weaker for people socialized in an interdependent self-schema culture, for example, the collectivists' countries. Moreover, the increasing role of global markets, financial institutions need to understand how to sell their products to different markets (Mooij, 2009).

\subsubsection{Relationship between Attitude and Behaviour}

Consumer behaviourists have long stressed on the attitudes to predict peoples' actions. Attitudes have been shown to significantly predict behaviour when: the person ascribes to a specific personality type with a high need for cognition; when relevant attitudes are consistent with the beliefs; and when attitudes are based on high levels of issue specific knowledge and/or personal experience and others. Literature also reveals that numerous methodological issues must be addressed if attitudes are to predict behaviour (Cohen and Reed, 2011). Attitude and behaviour should be measured at the same level of correspondence and at the same time among others (Tanner and Kast, 2010).

\subsubsection{Attitude-Behaviour Consistency}

The behaviour of the consumers usually lacks consistency with their attitudes for several reasons which include; the ability to do certain things, competing demand for resources, social influence (Hee and Chung, 2011). Measurement problems are also among the reasons. It is hard to measure attitudes. In most circumstances, consumers intentionally do not set out to count how positively or negatively they feel about a certain thing, and when a market researcher asks them about their beliefs about that thing, how significant these beliefs are, and their assessment of the performance of such item with respect to these beliefs, consumers usually do not give very reliable answers (Gupta and Ogden, 2009). Therefore, the consumers might act consistently with their true attitudes, which were never uncovered because a mistaken measurement was done.

\subsubsection{Theory of Reasoned Action and Theory of Planned Behaviour}

Alam and Sayuti (2011) assert that a number of theories have been put forward to advance knowledge on how attitudes predict behaviour. Firstly, the theory of reasoned action assumes that people consider the impact of their activities before they decide to engage or not to practice or embark on certain behaviour. As a result, people form intentions to perform behaviours which in turn stem from an individual's attitude towards the behaviour as well as his or her perception of others' opinions. The model primarily argues that people engage in processes that lead to attitudes formation, intentions and norms prior to performing the behaviour (Alam and Sayuti, 2011). However the Reasoned Action Theory was criticised by some scholars as it failed to support the relationship between behavioural intention and planned behaviour and this was as a result of the inconsistency and the minimum control over a person's action (Cohen and Reed, 2011). Therefore, to address the limitations above, the Theory of Planned Behaviour extends the Theory of Reasoned Action through the addition of a new component namely the perceived behavioural control (Ajzen, 2009). This idea originates from the Self Efficacy Theory (SET) and is viewed as similar to Bandura (1982) concept of self-efficacy which refers to the belief that one can successfully execute a behaviour required to produce an outcome. This theory was designed to explain and predict human behaviour in a specific context. Many researchers concur that, individuals may be likely to perform a specific type of behaviour if they are certain that the behaviour will result in particular favourable outcomes, if they have a reasonable belief that their referents will value the particular behaviour and have resources, abilities and opportunities necessary to conduct the specific behaviour (Kim and Han, 2010). In contrast with the Theories of Reasoned Action and Planned Behaviour, Kim and Han (2010) have suggested that attitudes guide behaviour through an automatic and spontaneous process instead of a deliberate one as highlighted by the earlier two theories. Kim and Han (2010) opine that two conditions command the probability that behaviours will be consistent with attitudes, that is when: the attitude is accessed spontaneously by the mere presence of the attitude object; and the attitude influences the perception of the object so that when the attitude is favourable (or unfavourable) the traits of the object are also viewed as favourable (or unfavourable).

Despite different theoretical reasoning presented on attitude-behaviour link, the attitudes are difficult to predict in the domain of environmental consumerism and this has remained debatable (Gupta and Ogden, 2009). 


\subsection{The Impact of Perceptions on Consumer Buying Patterns}

Schiffman (2010) states that perception can be viewed as how an individual organizes, selects and interprets stimuli into a coherent and meaningful image of the world. The aforementioned researcher highlights that individual consumers have perceived images of themselves; they also have perceived images of brands and products. Depending on certain situations namely; personal characteristics, experiences, and beliefs, consumers will interpret information and products differently from one another. Consumers' perception of a brand function is likely to be influenced by their cultural contexts since the brand is just a cultural vehicle (Kotler and Keller, 2013).

\subsubsection{Gestalt Principles}

Gestalt psychologists opine that certain features in visual perception are universal. One might say they are innate; they do not necessarily need to be taught. In this case these theories are known as sensual theories. These sensual theories are of a lower order of thinking than perceptual theories, such as semiotics, perceptual theories take into account the meaning we attach to what we see (Guo et al., 2011). Gestalt theory states that an individual see through incorporating a combination of light and dark on objects, contours and edges into a whole image without mere thinking about it. The statement, "the whole is different from the sum of its parts", sums up the way we recognize figures and whole forms instead of just a collection of simple lines, shapes and curves. Gestalt theory states that the brain operates holistically, with self-organizing tendencies. Gestalt states that we perceive the whole without knowing of the connection of the parts, and that the essence of the whole does not change when we reverse it. Gestalt psychologists have outlined important and universal principles of perceptual organization. The following are the principles by Gestalt theorists. Firstly, 'proximity, according to this principle, objects close together are viewed as perceptually organized as a unity. Consequently, objects that are not closer are viewed as separate. It is important to keep this principle because when designing print \& web based materials one should always focus on how the intended audience will interpret the graphics that will be employed. Secondly, the 'closure' principle involves an individual response to missing information when viewing an object that seems to be incomplete. People automatically try to make sense of the image and supply the information that is missing to give the complete image. When used in advertising, marketers usually supply only limited information in an advert seeking to encourage viewers to be drawn in and fill in the missing parts. Thirdly, the 'figure and ground' principle is premised on the notion that due to the confrontation by visual images, people try to separate a dominate shape, from a background. There is need to establish which part of the visual image is the background and what part stands out in the foreground. Both pictures can be held simultaneously. Figure-ground relationships influence how customers interpret images and make decisions based on what they would have interpreted. An individual will interpret a printed message differently according to which part of the image interpreted as the message and which part as the background. Fourthly, the 'similarity' principle, the principle has it that, the objects that are similar are grouped together. Customers usually interpret new information in a similar way to the information they already have and this have an impact on how consumers select the products to purchase.

\section{Research Methodology}

\subsection{Research Design}

Shajahan (2014) define research design as a theoretical plan for the gathering, measurement and analysis of data. It can also be defined as a process that permits a study to observe certain phenomena so as to give the researcher full information relating to the matter of concern. Creswell and Clark (2011) state that research designs are procedures for collecting, analysing, interpreting and reporting data in research studies. Generally, research design is categorised into three namely; the descriptive, the exploratory and the causal. Among these, the researchers made use of descriptive and exploratory research designs. Christensen and Johnson (2010) state that the primary objective of descriptive design is to enable an accurate description or picture of the status of a situation or phenomenon. Thus, this research design central objective was to describe the impact of psychological influence on consumer buying pattern and this necessitated the use of a descriptive research design. Alternatively, explorative research design was also employed in the study as the researchers wanted to get an in-depth understanding of the phenomena under study, as it allowed for probing on a one to one basis, fostering interaction between the interviewer and respondent.

\subsection{Population, Sample and Research Instruments}

Descombe (2010) states that population refers to all items in the group of objects being researched. In this study, the target population was the SMEs in the manufacturing industry in Harare. Statistics show that Harare has got 541456 SMEs of which only $11 \%$ of this number are in the manufacturing industry (Mugano, 2015). However it is argued that SMEs tend to enter and exit their businesses, thus the researchers estimated that the SMEs population in the manufacturing sector to be approximately 59560 SMEs inclusive of 4 policy advocates. Thus, based on this population, the following formula by Yamane (1967) was adopted to determine the sample size for the study:

$$
\mathrm{n}=\frac{N}{1+N(e)^{2}}
$$

Where: $\mathrm{n}=$ necessary sample size

$\mathrm{N}=$ estimated population size

$\mathrm{e}=$ margin of error

$\mathrm{n}=\frac{59560}{1+59560(0.1)^{2}}=99.83238351 \approx 100$

Source:Yamane (1967)

Using the margin error of $10 \%$, the formula above, gave a sample of 100 respondents inclusive of customers and policy advocates. Stratified random sampling was then used to select customers of SMEs products while purposive sampling technique was used to select policy advocates. Questionnaires were used to gather information from customers while an interview guide was used to gather data from policy advocates. 


\subsubsection{Research Findings}

3.2.1.1. The Effect of Personality on the Buying Behaviour of Consumers

$60 \%$ revealed that personality affect buying behaviour of SMEs products. $25 \%$ showed that they have never purchased products from SMEs and have no information on SMEs products. However $15 \%$ of respondents were neutral about the issue. $80 \%$ of the policy advocates showed that personality indeed has an influence in the buying intentions of customers while $20 \%$ indicated that it varies with the capacity of SMEs ability to supply the right product where it is wanted. Generally, the results showed a positive relationship between individual personality and purchasing behaviour. This is inconformity with a research conducted by Banerjee (2016) who argues that consumers associate human personality traits with brands because they view brands as an extension of their behaviour.

\subsubsection{Effect of Customer Perception on Consumer Buying Behaviour}

$75 \%$ of most respondents perceived SMEs products as of low quality and therefore showed that their propensity to purchase those products was very low. $15 \%$ revealed that they only purchase SMEs products if there are no alternatives available or substitute products, while $10 \%$ prefer to buy foreign manufactured brands only as these are more appealing and induce appetite as compared to locally manufactured products. $100 \%$ of policy advocates concurred that SMEs need to manufacture the right products demanded by customers and brand it properly so that customer perception towards those products is enhanced. The policy advocates have revealed that perception plays a critical part in marketing programmes, where pictures, images, spoken, \& written language, color, noise, music, tastes and smells are used in such profusion, and that, an understanding of how it works is an absolute must for all managers that work in a business which requires customers' input.

\subsubsection{The Effect of Attitudes on Consumer Buying Behaviour}

$55 \%$ of the customers revealed that they simply have a negative attitude with SMEs locally manufactured brands and therefore purchasing these brands is a waste of time. While $30 \%$ revealed that they experienced poor service delivery when purchasing SMEs products and indicated that if they discovered or report about a fault product or poor product, their complaints are not taken into consideration and sometimes they are never attended to either in time or simply get ignored. $15 \%$ revealed that they purchase any product as long as it is good to them. Furthermore, it was also noted that if consumer attitudes are not dealt with in time, then SMEs in the manufacturing sector might fail to be the preferred customer suppliers. This research is in line with Nepomuceno and Porto (2010) who argued that our personal attitudes influence most of our behaviours. $78 \%$ of policy advocates interviewed clearly concurred that negative attitudes by customers towards a product are quite ruinous and need to be attended to in time. $23 \%$ of policy advocates revealed that one way to make SMEs viable is to train them how to deal with negative attitudes from their customers and to advise them to be customer focused.

\section{Recommendations}

Considering the above views, the following recommendations were made:

- Since customers are likely to use products that are in line with their personality traits, SMEs and other organizations must reinforce a customer believe and recognize a brand personality and reinforcing the communication between the brand and the consumer in order to enhance brand loyalty and equity.

- Furthermore, organizations must impose personality traits on their brands such that consumers may relate to those brands as they would partner or friends with them.

- Companies must consider associating their products with human attitudes, increasing the likelihood that consumers will perceive the products as a way to express their personal values, which ultimately increase the link between the values and attitudes. More importantly, one's value system does not change easily. Hence, a personal value is a stable trait that can be used to target many market-oriented activities, without the concern of being easily affected by time or other uncontrolled variables.

\section{References}

Ajzen, I., 2009. A theory of planned behavior. Retrieved from http://people.umass.edu/aizen/tpb.html.

Alam, S. and N. Sayuti, 2011. Applying the theory of planned behavior (TPB) in halal food purchasing. International Journal of Commerce and Management, 21(1): 8-20. View at Google Scholar | View at Publisher

Anant, A. and J. Verma, 2014. Intrinsic factors affecting consumer buying behaviour: Evidence from India. Journal of Retailing and Consumer Services, 21(2): 537-549. View at Google Scholar | View at Publisher

Bandura, A., 1982. Self-efficacy mechanism in human agency. Journal of American Psychologist, 37(1): 122-147. View at Google Scholar | View at Publisher

Banerjee, S., 2016. Influence of consumer personality, brand personality, and corporate personality on brand preference: An empirical investigation of interaction effect. Asia Pacific Journal of Marketing and Logistics, 28(2): 198-2 16. View at Google Scholar |View at Publisher

Blythe, J., 2011. Consumer behaviour. London: Thomson Learning.

Boddy, R.C. and R. Croft, 2016. Marketing in a time of toxic leadership. Qualitative Market Research: An International Journal, 19(1): 44-64. View at Google Scholar | View at Publisher

Christensen, L. and B. Johnson, 2010. Educational research: Quantitative, qualitative, and mixed approaches. New York: Sage.

Cohen, J.B. and A. Reed, 2011. A multiple pathway anchoring and adjustment (MPAA) model of attitude generation and recruitment. Journal of Consumer Research, 33(1): 1-15. View at Google Scholar | View at Publisher

Creswell, J. and V. Clark, 2011. Mixed research methods. 2nd Edn., New York: Sage Publications.

Das, G., 2014. Store personality and consumer store choice behaviour: An empirical examination. Journal of Marketing Intelligence \& Planning, 32(3): 375-394. View at Google Scholar | View at Publisher

Descombe, M., 2010. The good research guide for small scale social research projects. 4th Edn., London: McGraw Hill.

Ekhlassi, A., M. Hassani, S. Far and K. Rahmani, 2012. The relationship between brand personality and customer personality, gender and income: A case of the cell phone market in Iran. Journal of Targeting, Measurement and Analysis for Marketing, 20(3): $158-171$. View at Google Scholar | View at Publisher

Govers, P.C.M. and J.P.L. Schoormans, 2012. Product personality and its influence on consumer preference. Journal of Consumer Marketing, 22(4): 189-197. View at Google Scholar | View at Publisher

Guo, X., W.A. Hao and X. Shang, 2011. Consumer perceptions of brand functions: An empirical study in China. Journal of Consumer Marketing, 28(4): 269 - 279. View at Google Scholar | View at Publisher 
Gupta, S. and T.D. Ogden, 2009. To buy or not to buy? A social dilemma perspective on green buying. Journal of Consumer Marketing, 26(6): 376 - 391. View at Google Scholar |View at Publisher

Hawkins, D., D. Mothersbaugh and A. Mookherjee, 2010. Consumer behaviour-building marketing strategy. 11th Edn., New Delhi: Tata McGraw Hill Education Private Limited.

Hee, Y.K. and J. Chung, 2011. Consumer purchase intention for organic personal care products. Journal of Consumer Marketing, 28(1): 40 47. View at Google Scholar | View at Publisher

Huang, H.H., V.W. Mitchell and R. Rosenaum-Elliott, 2012. Are consumer and brand personality the same? Psychology \& Marketing, 29(5): 334-349. View at Google Scholar

Ivens, B. and S.K. Valta, 2012. Customer brand personality perception: A taxonomic analysis. Journal of Marketing Management, 28(9-10): 1062-1093. View at Google Scholar |View at Publisher

Jani, D. and H. Han, 2014. Personality, satisfaction, image, ambience, and loyalty: Testing their relationship in the hotel industry. International Journal of Hospitality Management, 37(1): 11-20. View at Google Scholar | View at Publisher

Kim, Y. and H. Han, 2010. Intention to pay conventional-hotel prices at a green hotel-a modification of the theory of planned behavior. Journal of Sustainable Tourism, 18(8): 997-1014. View at Google Scholar | View at Publisher

Kim, Y.H. and J. Chung, 2011. Consumer purchase intention for organic personal care products. Journal of Consumer Marketing, 28(1): 40-

Kotler, P., 2011. Marketing management. 11 th Edn., Delhi: Pearson Education (Singapore) Pvt Ltd.

Kotler, P. and K.L. Keller, 2013. Marketing management. 12th Edn., Englewood Cliffs, NJ: Prentice-Hall.

Lin, Y.L., 2010. The relationship of consumer personality trait, brand personality and brand loyalty: An empirical study of toys and video games buyers. Journal of Product \& Brand Management, 19(1): 4-17. View at Google Scholar |View at Publisher

Majaka, N., 2015. Government mulls new tax regime. Daily News, 24th 2015: 13.

Migliore, A.L., 2011. Relation between big five personality traits and Hofstede's cultural dimensions samples from the USA and India. Cross Cultural Management: An International Journal, 18(I): 38 - 54. View at Google Scholar | View at Publisher

Mohammad, A., 2015. How the personality of retail bank customers interferes with the relationship between service quality and loyalty. International Journal of Bank Marketing, 33(1): 41-57. View at Google Scholar | View at Publisher

Mooij, M., 2009. Global marketing and advertising: Understanding cultural paradoxes. 3rd Edn., Thousand Oaks. CA: Sage.

Mugano, G., 2015. Establish SME export development and promotion agency. The Herald. Oct 8.

Muleya, T., 2015. Rising smuggling cases worries Zimra. The Herald, 11 th Aug: 13.

Muleya, T., 2016. Zimra introduces hand scanners at Beitbridge border post. The Herald, 26th Feb: 9.

Mulyanegara, R., 2010. Predicting brand preferences. Journal of Fashion Marketing and Management: An International Journal, 13(3): 358371.

Nepomuceno, V. and J. Porto, 2010. Human values and attitudes toward bank services in Brazil. International Journal of Bank Marketing, 28(3): 168-192. View at Google Scholar | View at Publisher

Schiffman, L.G., 2010. Consumer behaviour. India: Pearson Education.

Shajahan, S., 2014. Introduction to research methods. Mumbai: Jaico Publishing House.

Sibanda, G., 2015. Bans, duty hike on used imports. The Herald, 31 st July: 5.

Tanner, C. and S.W. Kast, 2010. Promoting sustainable consumption: Determinants of green purchases by Swiss consumers. Psychology and Marketing, 20(10): 883-902. View at Google Scholar | View at Publisher

Xiaoling, G., A.W. Hao and X. Shang, 2011. Consumer perceptions of brand functions: An empirical study in China. Journal of Consumer Marketing, 28(4): 269-279. View at Google Scholar | View at Publisher

Yamane, T., 1967. Statistics an introductory analysis. New York: Harper and Row.

Citation | Godwell Karedza; Mike Sikwila; T.B. Bhebhe (2017). The Impact of Psychological Influences on Consumer Buying Behavior Zimbabwe. Asian Business Research Journal, 2: 1-7.

History:

Received: 15 March 2017

Revised: 22 March 2017

Accepted: 29 March 2017

Published: 5 April 2017

Licensed: This work is licensed under a Creative Commons

Attribution 3.0 License (oc)

Publisher: Eastern Centre of Science and Education
Acknowledgement: All authors contributed to the conception and design of the study.

Funding: This study received no specific financial support.

Competing Interests: The authors declare that they have no conflict of interests.

Transparency: The authors confirm that the manuscript is an honest, accurate, and transparent account of the study was reported; that no vital features of the study have been omitted; and that any discrepancies from the study as planned have been explained.

Ethical: This study follows all ethical practices during writing.

Eastern Centre of Science and Education is not responsible or answerable for any loss, damage or liability, etc. caused in relation to/arising out of the use

of the content. Any queries should be directed to the corresponding author of the article. 